\title{
PENGARUH Nigella sativa TERHADAP CD4+IL5, CD8+IL5, DAN KADAR INTERLEUKIN 5 SERUM PADA ANAK ASMA RINGAN DAN SEDANG
}

\author{
Tommy Nugroho Wirawan ${ }^{\star 凶}$, Wisnu Barlianto** HMS Chandra Kusuma**
}

\begin{abstract}
Abstrak
Asma merupakan penyakit inflamasi kronis pada saluran napas yang menjadi masalah kesehatan di dunia. Respons inflamasi pada pasien asma melibatkan banyak reaksi yang saling terkait antara epitel organ respirasi, sistem imun alami dan adaptif yang ditunjukkan oleh aktivasi Th2. Salah satu sel efektor yang penting pada eksaserbasi asma eosinofil yang aktivasinya diperantarai sitokin IL-5. IL-5 dihasilkan oleh CD4+ dan $\mathrm{CD}^{+}$. Nigella sativa mengandung thymoquinone yang berfungsi sebagai imunomodulator. Tujuan penelitian adalah mengkaji efek pemberian Nigella sativa terhadap IL-5 serum dan jumlah sel CD4+IL-5+ dan $\mathrm{CD} 8^{+} \mathrm{LL}-5^{+}$pada anak asma ringan dan sedang. Desain penelitian adalah pre-post controlled study. Sebanyak 28 anak dengan rentang usia 5-18 tahun yang dibagi menjadi empat kelompok perlakuan, yaitu kelompok $\mathrm{A}$ dan $\mathrm{B}$ : asma ringan dan sedang dengan terapi standar; Kelompok $\mathrm{C}$ dan $\mathrm{D}$ : asma ringan dan sedang dengan terapi standar + Nigella sativa dengan dosis $600 \mathrm{mg}$ per hari $(15-30 \mathrm{mg} / \mathrm{kgBB} / \mathrm{hari})$ dan diberikan selama 8 minggu. Kadar IL-5 serum tidak berbeda bermakna pada semua kelompok sebelum dan setelah perlakuan $(p>0,05)$, serta jumlah sel $C D 4^{+} \mid L-5^{+}$dan $C D 8^{+} \mid L-5^{+}$tidak berbeda antara sebelum dan setelah perlakuan kecuali pada kelompok A (asma ringan + terapi standar). Nigella sativa tidak memberikan perbedaan signifikan terhadap kadar IL-5 serum, jumlah sel $\mathrm{CD} 4^{+} \mathrm{IL}-5^{+}$dan $\mathrm{CD} 8^{+} \mathrm{IL}-5^{+}$dibandingkan terapi standar baik pada asma ringan maupun sedang $(p>0,05)$. Uji korelasi menunjukkan tidak ada korelasi signifikan antara kadar IL-5 serum, jumlah sel $\mathrm{CD} 4^{+} \mathrm{IL}-5^{+}$dan $\mathrm{CD} 8^{+} \mathrm{IL}-5^{+}$pada kelompok asma ringan dan sedang. Pemberian Nigella sativa tidak menurunkan kadar IL-5 serum, jumlah sel CD4+IL-5+ dan CD8+IL-5+ darah secara signifikan serta tidak didapatkan korelasi antara kadar IL-5 serum, jumlah sel CD4+IL-5+ dan $\mathrm{CD} 8^{+} \mathrm{IL}-5^{+}$darah pada kelompok asma ringan dan sedang.

Kata kunci: asma, interleukin $5, \mathrm{CD}^{+}, \mathrm{CD}^{+}$.
\end{abstract}

\section{EFFECT OF Nigella sativa ADMINISTRATION TOWARD SERUM INTERLEUKIN-5 LEVEL, BLOOD CD4+IL-5+, AND CD8+IL-5+ CHILDREN WITH MILD AND MODERATE ASTHMA}

\begin{abstract}
Asthma is chronic inflammatory disease of airway which had been a serious health problem in the world. Inflammatory response in asthma is attributed by interaction of epithelial respiratory organs, innate and adaptive immune response and it is characterized mainly by Th2 activation. One of important effector cells involved in asthma excacerbation is eosinophil that is activated by cytokine IL-5. IL-5 is produced by both $\mathrm{CD4}^{+}$and $\mathrm{CD}^{+}$. Nigella sativa contains thymoquinone functioned as immunomodulator. This study aims to investigate the effect of Nigella sativa toward the level of IL-5 and number of CD4+IL-5+ cell and CD8+IL-5+ in children with mild and moderate asthma. This research was designed as pre-post controlled study. Twenty eight subjects 5-18 years old were divided into 4 treatment groups as follow, group A and B: mild and moderate asthma with standard treatment; group $\mathrm{C}$ and $\mathrm{D}$ : mild and moderate asthma with standard treatment + Nigella sativa, dosage $600 \mathrm{mg}$ per day $(15-30 \mathrm{mg} / \mathrm{kgBB} /$ day $)$ and administered for 8 weeks. Serum IL-5 level was not significantly different among all groups between pre-treatment and post-treatment $(p>0.05)$. Furthermore, number of CD4+ IL-5+ and CD8 $8^{+} L-5^{+}$were not significantly different between pre and post treatment except for group A (mild asthma + standard treatment). Addition of Nigella sativa showed no significant differences on serum IL-5 level, cells count of CD4+IL-5+ and CD8+IL-5+ as compared to standard treatment both in mild or moderate asthma group $(p>0.05)$. Correlation study showed no significant association between serum IL-5 level, cell count of $\mathrm{CD} 4^{+} \mid \mathrm{L}-5^{+}$and $\mathrm{CD} 8^{+} \mathrm{IL}-5^{+}$both in mild or moderate asthma group. Addition of Nigella sativa would not reduce serum IL-5 level, cell count of CD4+IL-5+ and CD8+IL-5+ significantly. There was no significant association between serum IL-5 level, cell count of CD4+IL-5+ and CD8+IL-5+ both in mild or moderate asthma groups.

Keywords: asthma, interleukin-5, CD4, CD8, Nigella sativa

*Program Studi Magister (S2) IImu Biomedik, Fakultas Kedokteran, Universitas Brawijaya Malang

**Departemen IImu Kesehatan Anak, Fakultas Kedokteran, Universitas Brawijaya - RSUD. Dr. Saiful Anwar Malang
\end{abstract}

E-mail: tommynugroho77@gmail.com 


\section{Pendahuluan}

Asma merupakan penyakit inflamasi kronis pada saluran napas yang saat ini menjadi masalah kesehatan dunia yang serius dan mempengaruhi semua kelompok usia, dengan peningkatan risiko prevalensi dan biaya perawatan pada banyak negara berkembang. ${ }^{1,2}$ Berdasarkan National Health Interview Survey (NHIS), sebanyak 39,5 juta penduduk atau 129,1 per 1000 penduduk Amerika menderita asma. Prevalensi asma di seluruh dunia meningkat $50 \%$ per dekade dalam dua dekade terakhir, baik di negara maju maupun di negara berkembang. ${ }^{3}$ Menurut ISAAC III (Internasional Study of Asthma and Allergy in Childhood) pasien anak asma usia 13 - 14 tahun dari tahun 2000 - 2003 di Indonesia sebanyak 2,6\%, pembagian berdasar prevalensi asma anak sekitar $10 \%$ ada pada anak usia sekolah dasar, dan sekitar $6,5 \%$ pada anak usia sekolah menengah pertama. ${ }^{2}$

Patogenesis utama pada asma adalah respons inflamasi yang melibatkan reaksi yang saling terkait antara epitel organ respirasi, sistem imun alami dan adaptif yang mengawali dan menyebabkan terjadinya respons proses inflamasi kronis. Penelitian menunjukkan respons Th2 $\left(\mathrm{CD}^{+}\right)$memegang peranan penting dalam patogenesis asma melalui sekresi dari sitokin interleukin-4 (IL-4) dan interleukin-13 (IL-13), dan IL-5 yang akan menginduksi proses inflamasi pada asma. ${ }^{4}$ Selain sel T $\mathrm{CD}^{+}$(TCD4), sel T sitotoksik 2 (TC2, $\mathrm{TCD}^{+}$) juga memiliki peranan penting pada patogenesis asma. ${ }^{5}$ Interleukin 5 (IL-5) merupakan sitokin proinflamasi yang dihasilkan oleh sel Th2 $\left(\mathrm{CD} 4^{+}\right)$maupun Tc2 $\left(\mathrm{CD}^{+}\right)$, mast, group 2 innate lymphoid cells (ILC 2), CD34+ progenitor cells, sel natural killer (NK), maupun eosinofil yang kemudian akan merangsang respons inflamasi pada

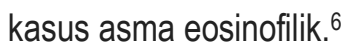

Tujuan jangka panjang tatalaksana asma adalah pengendalian gejala dan mengurangi risiko. Global Initiative for
Asthma (GINA) mencantumkan peningkatan kualitas hidup merupakan salah satu tujuan dari tatalaksana asma. Tujuan tatalaksana asma anak secara umum adalah mencapai kendali asma sehingga menjamin tercapainya potensi tumbuh kembang anak secara optimal. Obat-obatan asma tidak menyembuhkan asma secara total dan penghentian terapi akan menimbulkan gejala kekambuhan. ${ }^{1}$ Oleh karena itu, diperlukan studi untuk mencari alternatif lain dari pengobatan dan pengendalian asma. Imunomodulator adalah berbagai macam agen atau intervensi imunologis yang dapat merubah respons imun dengan jalan menekan ekspresi sel leukosit, menginduksi deviasi respons imun, toleransi atau memodifikasi jalur inflamasi. Aktivasi Th2 dan jalur aktivasi eosinofil melalui IL-5 merupakan salah satu target terapi yang penting pada anak dengan asma. Beberapa penelitian telah melaporkan uji klinis pada antibodi monoklonal maupun poliklonal terhadap IL-5 memberikan hasil yang positif pada penurunan kadar eosinofil dengan atau tanpa perbaikan klinis (dengan asthma control questionnaire dan uji fungsi paru). ${ }^{7}$

Nigella sativa berpotensi sebagai imunomodulator serta memiliki efek antiinflamasi. Kandungan Nigella sativa berupa asam linoleat dan thymoquinone memiliki efek antiinflamasi yang bermanfaat pada asma. Pemberian thymoquinone, zat aktif pada Nigella sativa juga dapat menurunkan jumlah ekspresi eosinofil, neutrofil dan basofil pada hewan coba yang diinduksi asma. ${ }^{8}$ Penelitian pada manusia tentang efek thymoquinone sampai saat ini masih sangat terbatas dengan hasil yang sangat bervariasi. Oleh karena itu, pada penelitian ini akan dikaji efek pemberian Nigella sativa terhadap kadar IL-5 serum, jumlah sel limfosit CD4+|L-5 dan jumlah sel limfosit $C D 8^{+} \mid L-5$ pada darah anak asma ringan dan sedang. 


\section{Bahan dan Metode}

Penelitian ini merupakan penelitian eksperimental dengan desain randomized clinical trial. Subjek dibagi menjadi 4 kelompok yang masing-masing kelompok 7 sampel dan total 28 sampel., dengan perlakuan pada kelompok $\mathrm{A}$ (asma ringan) dan B (asma sedang) terapi standar, kelompok C (asma ringan) dan D (asma sedang) diberikan terapi standar dan Nigella sativa. Seluruh perlakuan diberikan selama 8 minggu. Penelitian ini dilaksanakan pada bulan Januari-September 2016 di Poli Respirologi Anak Rumah Sakit Saiful Anwar (RSSA) Malang dan Laboratorium Biomedik Fakultas Kedokteran Brawijaya Malang. Populasi penelitian ini adalah semua anak yang didiagnosis asma serta memenuhi kriteria inklusi dan eksklusi di Poli Respirologi Anak RSSA Malang. Subjek adalah pasien asma ringan dan sedang. Penelitian ini telah disetujui oleh komite etik penelitian Universitas Brawijaya Malang dengan nomor surat 369/EC/KEPK/06/2015.

Teknik pengambilan subjek penelitian dengan metode consecutive sampling kemudian dilakukan randomisasi. Kriteria inklusi yaitu anak yang didiagnosis asma ringan dan sedang berdasarkan Global Initiative for Asthma (GINA), berusia antara 5-14 tahun, pasien dan orang tua pasien bersedia secara sukarela mengikuti penelitian dan menandatangani informed consent, sedangkan kriteria eksklusi yaitu pasien yang menderita imunodefisiensi, penyakit autoimun atau memiliki kelainan kardiovaskular, pasien menderita komorbid atau penyakit saluran pernafasan lain seperti sinusitis, pneumonia, tuberkulosis dan kelainan anatomi seperti polip hidung, pasien memiliki riwayat alergi berat seperti syok anafilaksis dan asma serangan berat yang mengancam jiwa (life-threatening asthma), memiliki riwayat gagal napas atau pernah diintubasi dalam 6 bulan terakhir, pasien sedang mengalami serangan asma.

Bahan pemeriksaan berasal dari pungsi vena. Pengambilan sampel darah dilakukan pada awal perlakuan dan setelah minggu ke-8 di Laboratorium RSSA oleh petugas laboratorium. Sampel darah ditampung dalam tabung. Volume darah yang diambil pada masing-masing sampel penelitian adalah $5 \mathrm{ml}$. Sebanyak $3 \mathrm{ml}$ sampel darah dipisahkan untuk pemeriksaan flow cytometry yang dilakukan di Laboratorium Biomedik Fakultas Kedokteran Universitas Brawijaya Malang. Sisanya sebanyak $2 \mathrm{ml}$ sampel darah diambil serumnya dan disimpan pada suhu $4^{\circ} \mathrm{C}$ untuk dilakukan pengukuran kadar IL-5 serum menggunakan Elisa Kit Cat. No. ELHIL5. Hasil pemeriksaan ELISA dibaca menggunakan Biorad Microplate Reader panjang gelombang $550 \mathrm{~nm}$.

Pengukuran Jumlah Sel Limfosit CD4+ $\mathrm{LL}-5^{+}$ dan Limfosit CD8+IL-5+Darah

Sampel darah yang diambil dengan penambahan heparin diencerkan dengan RPMI (BioWhittaker) dan 2\% calf serum dan setelah penambahan $25 \mu \mathrm{l}(25 \mathrm{ng} / \mathrm{ml})$ phorbol 12-myristate 13-acetate (PMA; Sigma), $20 \mu \mathrm{l}(1 \mu \mathrm{g} / \mathrm{ml})$ ionomycin (Sigma), dan $10 \mu \mathrm{l}(2,5 \mu \mathrm{M})$ monensin (Sigma) kemudian diinkubasi pada water bath selama 4 jam pada suhu $37{ }^{\circ} \mathrm{C}$. Sampel darah yang telah distimulasi tersebut kemudian didistribusikan pada $100 \mu$ liquot ke tabung yang mengandung $20 \quad \mu \mathrm{l}$ antihuman CD4-FITC dan CD8-PerCp (Becton Dickinson), divortex, dan diinkubasi selama 20 menit pada suhu ruang dan gelap. Untuk memfiksasi sel, $100 \mu \mathrm{l}$ IntraPrep Reagent 1 (DAKO) ditambahkan pada masing-masing sampel diikuti vortex dan inkubasi selama 15 menit pada suhu ruang dan gelap kemudian diikuti proses washing dengan $2 \mathrm{ml}$ cell wash solution. Permeabilisasi simultan pada leukosit dan 
lisis eritrosit dilakukan dengan cara menambahkan $100 \mu \mathrm{l}$ IntraPrep Reagent 2 (DAKO) dan inkubasi. Prosedur pengecatan intraseluler meliputi penambahan $20 \mu \mathrm{l}$ antibodi monoclonal anti-IL-5 terkonjugasi dengan PE (Coulter Immunotech). Analisis hasil flow cytometry dilakukan dengan mesin FACS-Calibur (Becton Dickinson). Hasil scan ini akan memperlihatkan persentase jumlah sel $\mathrm{CD}^{+}$yang memproduksi IL-5 dan sel $\mathrm{CD}^{+}$yang memproduksi IL-5. Aktivasi sel dikonfirmasi dengan melihat ekspresi CD69 yang akan diekspresikan $95 \%$ pada semua sampel. Analisis hasil scan dilakukan dengan menggunakan software Cell Quest (Becton Dickinson). ${ }^{9}$

Teknik analisis statistik

Analisis statistik dilakukan dengan menggunakan SPSS 16.0 (SPSS Inc, USA). Data deskriptif ditampilkan dalam bentuk rerata $\pm S D$. Analisis uji beda yang digunakan adalah ANOVA bila data parametrik dan Kruskal Wallis bila data non parametrik. Nilai p dikatakan signifikan bila $<0,05$.
Hasil

Penelitian ini melibatkan 28 anak asma ringan dan sedang (rentang usia 5-14 tahun) yang dibagi menjadi 4 kelompok yaitu kelompok $A$ : asma ringan terapi standar, kelompok B: asma sedang terapi standar, kelompok C: asma ringan terapi standar + Nigella sativa, dan kelompok D: asma sedang terapi standar + Nigella sativa. Pasien merupakan pasien rawat jalan di Poli Alergi dan Imunologi dan Poli Respirologi Anak Rumah Sakit Umum Dr. Saiful Anwar Malang. Tidak ada subjek yang mengalami drop out pada penelitian ini. Tabel 1 menunjukkan bahwa pada keempat kelompok perlakuan, jenis kelamin laki-laki dan perempuan memiliki jumlah yang hampir sama. Karakteristik responden berdasarkan umur diketahui pada rentang usia 7-9 tahun. Hasil uji statistik menunjukkan bahwa tidak ada perbedaan usia di antara keempat kelompok (Kruskal Wallis, $p>0,05$ ). (Tabel 1).

Tabel 1. Karakteristik subjek penelitian.

\begin{tabular}{l|c|c|c}
\hline & \multicolumn{2}{|c|}{ Jenis kelamin } & \\
\hline Karakteristik Responden & Perempuan & Laki-laki & Rerata usia \\
\hline Kelompok A (n=7) & $4(4 / 7)$ & $3(3 / 7)$ & $7.6 \pm 4,2$ \\
\hline Kelompok B (n=7) & $3(3 / 7)$ & $4(4 / 7)$ & $9.8 \pm 5,4$ \\
\hline Kelompok C (n=7) & $4(4 / 7)$ & $3(3 / 7)$ & $7.07 \pm 6,5$ \\
\hline Kelompok D (n=7) & $4(4 / 7)$ & $3(3 / 7)$ & $9.5 \pm 5,8$ \\
\hline p yalue & & & 0.339 (Kruskal-Wallis) \\
\hline
\end{tabular}

Perbedaan Persentase Sel CD8+-IL-5 Darah Sebelum dan Setelah Perlakuan

Analisis perbandingan persentase sel limfosit $\mathrm{CD}^{+}-\mathrm{IL}-5$ darah sebelum dan setelah perlakuan pada masing-masing kelompok menggunakan uji paired T-test (kelompok A, C, dan D) dan uji alternatif Wilcoxon (kelompok B). Hasil uji (Gambar 2) menunjukkan adanya perbedaan signifikan antara sebelum dan setelah perlakuan pada kelompok $A$ (asma ringan + terapi standar) $(p=0,043)$, tetapi tidak untuk kelompok $B$ (asma sedang + terapi standar) $(p=0,072)$, kelompok C (asma ringan + terapi standar + Nigella sativa) $(p=0,138)$, dan kelompok $D$ (asma sedang + terapi standar + Nigella sativa) $(p=0,961)$. 


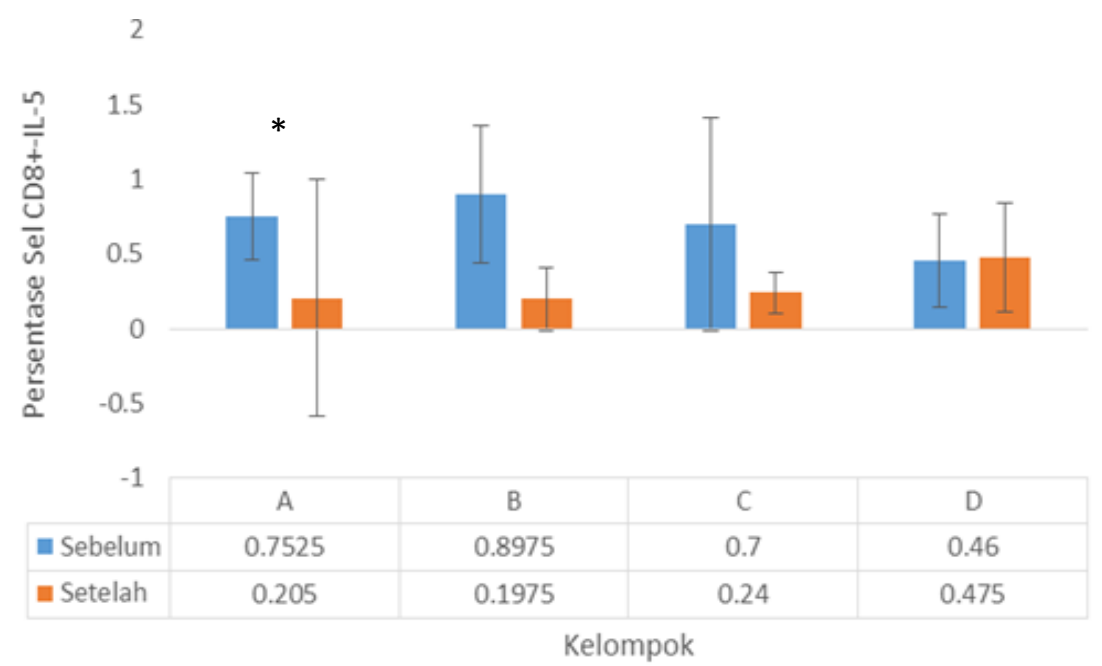

Gambar 2. Perbedaan persentase sel limfosit CD8+-IL-5 darah sebelum dan setelah perlakuan. Keterangan: Kelompok A (asma ringan + terapi standar), kelompok B (asma sedang + terapi standar), kelompok C (asma ringan + terapi standar + Nigella sativa), kelompok D (asma sedang + terapi standar + Nigella sativa), nilai $p<0,05$ signifikan (tanda *).

Perbedaan Persentase Sel Limfosit CD4+-IL5 Darah Sebelum dan Setelah Perlakuan

Analisis perbandingan persentase sel limfosit $\mathrm{CD}^{+}-\mathrm{IL}-5$ darah sebelum dan setelah perlakuan pada masing-masing kelompok menggunakan uji paired T-test (kelompok A, B, dan C) dan uji Wilcoxon sebagai uji alternatif (kelompok D) (Gambar 3). Hasil uji menunjukkan adanya perbedaan signifikan antara sebelum dan setelah perlakuan pada kelompok $\mathrm{A}$ (asma ringan + terapi standar) $(p=0,032)$, tetapi tidak untuk kelompok B (asma sedang + terapi standar) $(p=0.061)$, kelompok $C$ (asma ringan + terapi standar + Nigella sativa) $(p=0,157)$, dan kelompok $D$ (asma sedang + terapi standar + Nigella sativa) $(p=0,718)$.

Analisis perbandingan kadar IL-5 serum sebelum dan setelah perlakuan pada masing-masing kelompok menggunakan uji paired T-test (Gambar 4). Hasil uji menunjukkan tidak ada perbedaan signifikan antara sebelum dan setelah perlakuan pada kelompok $\mathrm{A}$ (asma ringan + terapi standar) $(p=0,433$ ), kelompok $B$ (asma sedang + terapi standar) $(p=0,663)$, kelompok $C$ (asma ringan + terapi standar + Nigella sativa) $(p=0,881)$, dan kelompok $D$ (asma sedang + terapi standar + Nigella sativa) $(p=$ $0,913)$. 


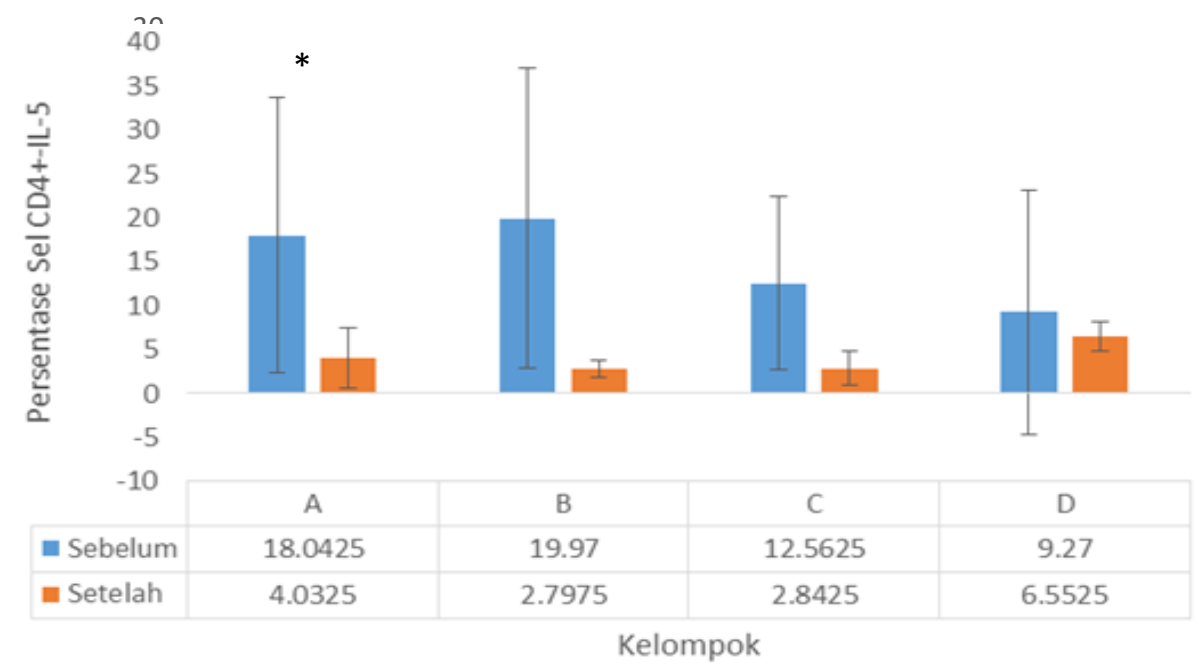

Gambar 3. Perbedaan persentase sel limfosit CD4+-IL-5 darah sebelum dan setelah perlakuan. Keterangan: Kelompok A (asma ringan + terapi standar), kelompok B (asma sedang + terapi standar), kelompok C (asma ringan + terapi standar + Nigella sativa), kelompok D (asma sedang + terapi standar + Nigella sativa), nilai $p<0,05$ signifikan (tanda *).

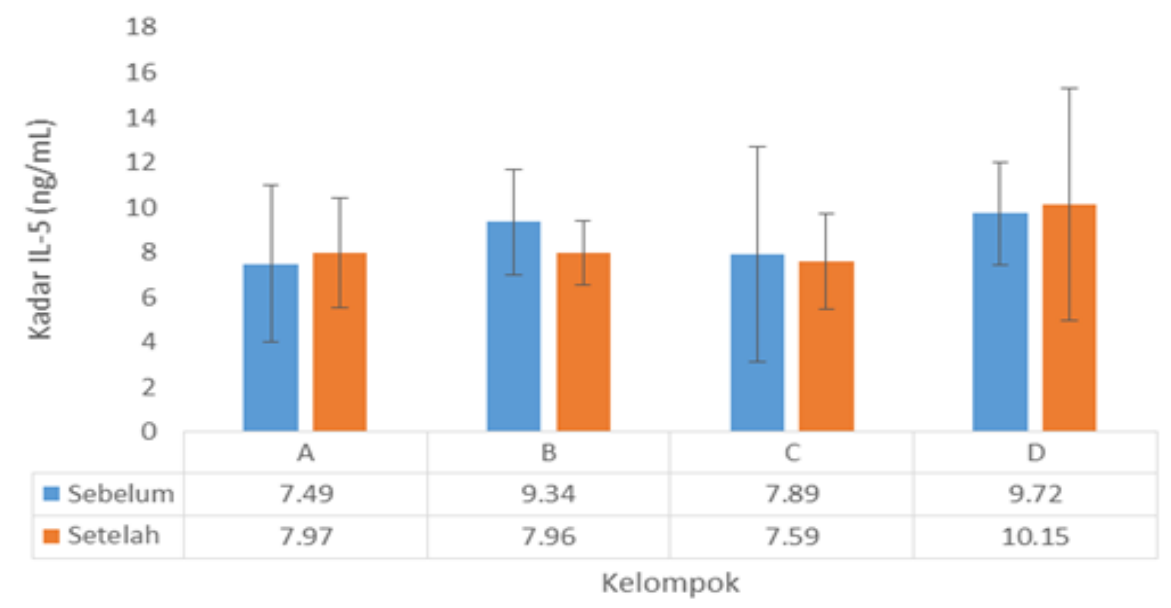

Gambar 4. Perbedaan kadar IL-5 serum sebelum dan setelah perlakuan.

Keterangan: Kelompok A (asma ringan + terapi standar), kelompok B (asma sedang + terapi standar), kelompok C (asma ringan + terapi standar + Nigella sativa), kelompok D (asma sedang + terapi standar + Nigella sativa), nilai $p<0,05$ signifikan (tanda *).

Perbedaan Persentase Sel Limfosit CD8+-IL5, Limfosit CD4+-IL-5 Darah dan Kadar IL-5 Serum Sebelum Perlakuan

Analisis perbandingan persentase sel limfosit CD8 ${ }^{+}-$IL-5 (Gambar 2), limfosit CD4+IL-5 darah (Gambar 3), dan kadar IL-5 serum (Gambar 4), sebelum perlakuan pada 4 kelompok menggunakan uji $\mathrm{T}$ tidak berpasangan. Perbandingan antar kelompok yang memiliki perbedaan bermakna secara statistik adalah pada perbandingan persentase sel limfosit CD8+-IL-5 dan limfosit CD4+-IL-5 darah antara kelompok B (asma sedang dengan terapi standar) dan kelompok D (asma sedang dengan terapi standar + terapi Nigella sativa). 
Perbedaan Persentase Sel Limfosit CD8+-IL5, Limfosit CD4+-IL-5 Darah dan Kadar IL-5 Serum Setelah Perlakuan

Analisis perbandingan persentase sel limfosit CD8+-IL-5 (Gambar 2),, limfosit CD4+-IL-5 darah (Gambar 3), dan kadar IL-5 serum (Gambar 4), setelah perlakuan pada 4 kelompok menggunakan uji $T$ tidak berpasangan. Hasil uji menunjukkan tidak ada perbedaan signifikan antara kelompok asma ringan maupun sedang yang diterapi standar dengan ditambahkan terapi Nigella sativa.

Hubungan antara Persentase Sel Limfosit CD8+-IL-5, Limfosit CD4+-IL-5 Darah dan Kadar IL-5 Serum

Hasil uji korelasi Pearson menunjukkan tidak ada hubungan antara persentase sel limfosit CD8 ${ }^{+}-\mathrm{IL}-5$, limfosit CD4+-IL-5 darah dan kadar IL- 5 serum baik pada asma ringan maupun sedang (Tabel 2).

Tabel 2. Uji korelasi Pearson hubungan antara persentase sel limfosit CD8 ${ }^{+}-I L-5$, limfosit CD4+-IL-5 darah dan kadar IL-5 serum.

\begin{tabular}{|c|c|c|c|c|}
\hline & Kelompok & Korelasi (r) & $\mathbf{P}$ & Keterangan \\
\hline \multirow{2}{*}{$\begin{array}{l}\text { Korelasi } \\
\text { Persentase Sel } \\
\text { limfosit CD8+-IL- } \\
5 \text { dan CD4+-IL-5 }\end{array}$} & Asma Ringan & $-0,040$ & 0,907 & Tidak ada hubungan \\
\hline & Asma Sedang & $-0,190$ & 0,625 & Tidak ada hubungan \\
\hline \multirow{2}{*}{$\begin{array}{l}\text { Korelasi } \\
\text { Persentase Sel } \\
\text { limfosit CD8+-IL- } \\
5 \text { dan Kadar IL-5 }\end{array}$} & Asma Ringan & $-0,267$ & 0,428 & Tidak ada hubungan \\
\hline & Asma Sedang & $-0,085$ & 0,827 & Tidak ada hubungan \\
\hline \multirow{2}{*}{$\begin{array}{l}\text { Korelasi } \\
\text { Persentase Sel } \\
\text { limfosit CD4+-IL- } \\
5 \text { dan IL-5 }\end{array}$} & Asma Ringan & 0,035 & 0,919 & Tidak ada hubungan \\
\hline & Asma Sedang & 0,086 & 0,826 & Tidak ada hubungan \\
\hline
\end{tabular}

\section{Pembahasan}

Berdasarkan karakteristik subjek jenis kelamin, jumlah laki-laki dan perempuan hampir sama dan tidak ada perbedaan signifikan di antara keempat kelompok perlakuan. Selain itu, berdasarkan faktor umur didapatkan rentang usia rata-rata 7 - 9 tahun dan hasil uji statistik menunjukkan bahwa tidak ada perbedaan usia di antara keempat kelompok. Hal ini merupakan prasyarat utama supaya tidak terjadi bias pada hasil penelitian terutama yang berkaitan dengan faktor jenis kelamin dan usia.
Analisis perbandingan persentase sel limfosit CD8 ${ }^{+}$IL-5 darah sebelum dan setelah perlakuan pada masing-masing kelompok menggunakan uji paired T-test (kelompok A, C, dan D) dan uji alternatif Wilcoxon (kelompok B). Hasil uji menunjukkan adanya perbedaan signifikan antara sebelum dan setelah perlakuan pada kelompok A (asma ringan + terapi standar), tetapi tidak pada kelompok B (asma sedang + terapi standar), kelompok C (asma ringan + terapi standar + Nigella sativa), dan kelompok $D$ (asma sedang + terapi standar + Nigella sativa). Hal ini menunjukkan asumsi bahwa terapi standar pada kelompok 
asma ringan mampu menurunkan jumlah sel limfosit $C D 8^{+}-$IL-5 darah dan penambahan terapi Nigella sativa tidak terlalu berpengaruh pada penurunan sel limfosit CD8+-IL-5 darah.

Analisis perbandingan persentase sel limfosit $\mathrm{CD}^{+}-\mathrm{IL}-5$ darah sebelum dan setelah perlakuan pada masing-masing kelompok menggunakan uji paired $T$ test (kelompok A, B, dan C) dan uji Wilcoxon sebagai uji alternatif (kelompok D). Ada perbedaan signifikan antara sebelum dan setelah perlakuan pada kelompok A (asma ringan + terapi standar), tetapi tidak untuk kelompok B (asma sedang + terapi standar), kelompok C (asma ringan + terapi standar + Nigella sativa), dan kelompok D (asma sedang + terapi standar + Nigella sativa). Hasil penelitian diketahui bahwa jumlah sel limfosit CD4+-IL-5 darah menunjukkan asumsi yang sama bahwa terapi standar pada kelompok asma ringan mampu menurunkan jumlah sel limfosit CD4+-IL-5 darah dan penambahan terapi Nigella sativa tidak terlalu berpengaruh pada penurunan sel limfosit CD4+-IL-5 darah.

Analisis perbandingan kadar IL-5 serum sebelum dan setelah perlakuan pada masing-masing kelompok menggunakan uji paired $T$ test menunjukkan tidak ada perbedaan signifikan antara sebelum dan setelah perlakuan pada semua kelompok. Penelitian mengenai peran $\mathrm{CD} 4^{+}$dan $\mathrm{CD} 8^{+}$ penghasil IL-5 maupun IL-5 saja pada patogenesis asma telah banyak diteliti, terutama pada kasus asma eosinofilik. ${ }^{6}$ Namun demikian, interaksi antara kedua sel tersebut serta implikasinya pada perburukan asma masih dalam proses investigasi. ${ }^{6}$ Peningkatan sel limfosit $\mathrm{TCD}^{+}$dalam saluran napas pasien asma dibuktikan dari hasil biopsi bronkus dari pasien asma atopik dan non atopik yang mengandung sel limfosit TCD8 ${ }^{+}$yang menghasilkan IL-4 dan IL-5. ${ }^{12}$ Machura et al. (2010) melaporkan bahwa terjadi peningkatan produksi IL-4, IL-
5 dan IFNy oleh sel limfosit T CD8+ pada pasien asma. ${ }^{9}$ Pada pasien asma didapatkan perbedaan perilaku sel limfosit $\mathrm{TCD}^{+}$dari darah perifer dan sel limfosit $\mathrm{TCD}^{+}$yang berada di saluran napas. ${ }^{9} \mathrm{Hal}$ ini mungkin mencerminkan preferential homing atau perubahan aktivasi yang yang disebabkan oleh faktor lingkungan pada saluran napas. ${ }^{10}$

Penelitian Lloyd et al. (2009) baik pada model manusia maupun hewan coba memberikan bukti bahwa sel Th2, melalui produksi sitokin seperti interleukin-4 (IL-4), IL-5 dan IL-13, merupakan kunci utama patofisiologi asma. Bukti bahwa IL-5 dihasilkan oleh sel limfosit $\mathrm{T} \mathrm{CD4}^{+}$dapat ditunjukkan melalui peningkatan sekresi IL-4 dan IL-5 pada sel limfosit $\mathrm{TCD}^{+}$yang diisolasi dari cairan bronchoalveolar lavage (BAL) pasien asma. ${ }^{10}$ Produksi sitokin Th2 awalnya diketahui berasal dari sel limfosit $\mathrm{TCD}^{+}$, namun sel limfosit TCD8 ${ }^{+}$mampu mensekresi sitokin Th2 dan juga penting dalam patofisiologi alergi dan sensitivitas saluran napas. ${ }^{9}$

Nigella sativa telah banyak diteliti mengenai efeknya sebagai imunomodulator pada berbagai penyakit termasuk asma. ${ }^{8}$ Thymoquinone sebagai zat aktif utama pada Nigella sativa memiliki efek antiinflamasi, dengan mekanisme menurunkan sitokin Th2 yaitu IL-4, IL-5 dan IL-13, IgE serum, eosinofil paru, 5-lipooksigenase dan siklooksigenase (COX) dalam metabolisme asam arakidonat, menghambat influk $\mathrm{Ca}^{2+}$ sehingga dapat mencegah degranulasi sel mast dan menurunkan TNF. ${ }^{11}$ Pemberian minyak biji Nigella sativa mampu menurunkan tingkat infiltrasi sel-sel radang pada saluran pernafasan. ${ }^{11}$ Pemberian thymoquinone pada mencit yang telah disensitisasi OVA menunjukkan penurunan $\lg E$ dan $\lg \mathrm{G} 1$ spesifik OVA, penurunan hiperplasia sel goblet dan penurunan produksi IL-4, IL-5 dan IL-13 dalam cairan bronchoalveolarlavage (BAL).Selain itu, 
ditunjukkan juga terjadinya perubahan Th2 ke Th1 setelah pemberian thymoquinon dengan terjadinya peningkatan IFN- $y .{ }^{12}$

Hasil penelitian ini sedikit berbeda dengan penelitian sebelumnya yaitu tidak ada perbedaan signifikan antara terapi asma dengan penurunan sel limfosit $\mathrm{CD}^{+}$dan limfosit $\mathrm{CD} 8^{+}$yang memproduksi IL-5. Hal ini dapat disebabkan oleh sumber sampel yang berbeda. Penelitian ini menggunakan sampel dari serum darah pasien dan mungkin kurang dapat merepresentasikan patogenesis asma pada pasien. Pengambilan sampel dari cairan bronchoalveolar lavage dapat dijadikan alternatif untuk mengukur parameter ini tetapi secara teknis hal ini sulit dilakukan pada pasien anak.

Untuk mengetahui status hubungan persentase sel limfosit CD8 ${ }^{+}-\mathrm{IL}-5$, limfosit CD4+-IL-5 darah dan kadar IL-5 serum digunakan uji korelasi Pearson. Hasil uji menunjukkan bahwa tidak ada hubungan antara persentase sel limfosit CD8 ${ }^{+}$IL-5, limfosit $\mathrm{CD}^{+}-\mathrm{IL}-5$ darah dan kadar IL-5 serum baik pada asma ringan maupun sedang. Interleukin 5 (IL-5) merupakan sitokin yang berperan penting dalam patofisiologi asma. IL-5 yang bertindak sebagai pencetus aktivasi eosinofil, mempengaruhi adhesi, ekspresi reseptor membran, kemotaksis dan sintesis mediatormediator inflamasi. ${ }^{10}$ Hasil penelitian menunjukkan tidak adanya korelasi antara jumlah sel limfosit $\mathrm{CD}^{+}$dan limfosit $\mathrm{CD}^{+}$ penghasil IL- 5 dengan kadar IL- 5 serum. Hal ini mungkin disebabkan oleh timing pengambilan sampel darah yang kurang tepat.

Keterbatasan penelitian ini meliputi beberapa hal yaitu timing pengambilan sampel darah berkaitan dengan eksaserbasi serangan asma, maupun jenis sampel yang dipertimbangkan. Penelitian selanjutnya diharapkan dapat menutupi kekurangan pada penelitian dengan menggunakan subjek yang lebih banyak, dan mungkin dengan desain yang lebih baik terutama pada timing pengambilan sampel dan lama pemberian Nigella sativa. Selain itu, karena thymoquinone sebagai zat aktif pada Nigella sativa telah menunjukkan efikasinya sebagai imunomodulator, mungkin perlu dilakukan penelitian mengenai pemberian thymoquinone pada jalur asma eosinofilik dengan menganalisis sitokin dan parameter yang lain sehingga didapatkan gambaran mengenai titik tangkap atau aktivitas dari Nigella sativa.

\section{Kesimpulan}

Pemberian Nigella sativa pada anak asma ringan maupun sedang yang mendapat terapi standar tidak menurunkan kadar IL-5 serum secara bermakna terutama pada kelompok asma sedang. Pemberian Nigella sativa pada anak asma ringan maupun sedang yang mendapat terapi standar dapat menurunkan persentase sel limfosit CD4+IL-5 dan CD8+IL-5 darah namun tidak bermakna secara statistik. Tidak didapatkan hubungan yang bermakna antara persentase sel limfosit CD8+IL-5, CD4+IL-5, dan kadar IL-5 serum pada anak asma ringan dan sedang.

\section{Saran}

Perlu dilakukan penelitian yang sama dengan menyertakan data persentase sel limfosit CD8+-IL-5, CD4+-IL-5, dan kadar IL-5 serum pada anak sehat, jumlah sampel yang lebih besar serta pemantauan ketepatan dosis terapi, cara konsumsi dan perlakuan Nigella sativa serta plasebo untuk kelompok kontrol.

\section{Daftar Pustaka}

1. Global Initiative Study for Asthma (GINA). Global Asthma Strategy of 
Management and Prevention, 2016. Cape Town: National Heart, Lung and Blood Institute. 2016.

2. Abbas AK, Litchman AH. Cellular and Molecular Immunology. $8^{\text {th }}$ Edition. Boston: Saunders. 2015.

3. Bergeron C, Boulet LP. Structural Changes in Airway Disease: Characteristic, Mechanisms, Consequences, and Pharmacologic Modulation. Chest. 2006. 129:1068-87.

4. Borees MP and Bjorrksten B. Peripheral Blood Eosinophils and IL-4 in Infacy in Relation to the Appereance of Allergic Disease During the First 6 Years of Life. Pediatr Allergy Immunol. 2004; 15:216220.

5. Lee SY, Kim SJ, Kwon SS, Kim YK, Kim $\mathrm{KH}$, Moon HS, Song JS, Park SH. Distribution and Cytokine Production of CD4 and CD8 T-lymphocyte Subsets in Patients with Acute Asthma Attacks. Ann Allergy Asthma Immunol. 2001; 86(6):659-64.

6. Nussbaum JC, Van Dyken SJ, von Moltke J, et al. Type 2 Innate Lymphoid Cells Control Eosinophil Hemostasis. Nature. 2013; 502: 245-248.

7. Nair P, Pizzichini MM, Kjarsgaard M, et al. Mepolizumab for Prednisone-
Dependent Asthma with Sputum Eosinophilia. New England Journal of Medicine. 2009; 360:985-993.

8. Azimi $E$, Athari SM, Afshari F, Eftekhari A, Athari SS. Effects of Black Seed (Nigella Sativa) on Type 2 Cytokines Gene Expression and Mucus Production in the Airways of Asthmatic Mice. Arch Med Lab Sci. 2016; 2(2): 46-53.

9. Machura E, Mazur B, Rusek-Zychma M, Barc-Czarnecka M. Cytokine Production in Peripheral Blood $\mathrm{CD}^{+}$and $\mathrm{CD} 8^{+} \mathrm{T}$ Cells in Atopic Childhood Asthma. Clinical and Developmental Immunology. 2010.

10. Lloyd CM and Hawrylowicz CM. Regulatory T Cells in Asthma. Immunity. 2009; 9.

11. Salem M. Immunomodulator and Therapeutics Properties of The Nigella sativa L. Seed. Int Immunopharmacol. 2005; 5:1749-1770.

12. Gazzar ME, Mezayen RE, Marecki J, Nicolls M, Canastar A, Dreskin S. AntiInflammatory Effect of Thymoquinone in A Mouse Model of Allergic Lung Inflammation. Int Immunopharmacol. 2006; 6:1135-42. 